\title{
THE INTERNET: A SUPPORT FOR PRESERVING AND FOSTERING THE QUALITY OF THE BASQUE LANGUAGE
}

\author{
Julian Maia-Larretxea, Kepa Larrea-Muxika \\ University of the Basque Country
}

\begin{abstract}
The aim of this article is to show some indications of how Basque society is facing the challenge of the Internet and how it is using this new resource in order to preserve not only the presence of Basque but also the quality of the language itself. It is divided into 4 sections: 1 ) some general information about the situation of Basque; 2) how Basque society is reacting to the Internet; 3 ) some issues about the quality of the Basque language (kinds of services that can be provided via the Internet and potential users of them); 4) some resources offered by three of civil service institutions intended to help professionals use the Basque language more correctly and appropriately. In the end we conclude that the Internet in fact supplies useful tools and resources to preserve and foster the Basque language and, specifically, its linguistic quality; on the other hand, the society is being quite aware of the importance of the new tool and it is, consequently, reacting positively to the challenge of this new technology.
\end{abstract}

Keywords: minority languages, Internet, Basque language, language quality

\section{Introduction}

The best-known writer in the Basque language, Bernardo Atxaga, in a lecture given around 1980 at the Faculty of Philosophy and Letters of the University of the Basque Country, said that, until a very few years ago, the Basque speaking community was invisible to itself as a result of the fact that the Basque language was not used for official procedures. In the 1960's the only language used for official purposes in the Basque Country was Spanish (or French, in the Northern Basque Country). There was very little Basque language in the media (TV, radio and written press), or in the education system as a whole, or in public administration, whether state, provincial or local. 
As can be expected, in that kind of situation speakers tend not to use their language because they are likely to feel and think that it is useless and, therefore, they will not try to preserve or defend it. That was what Bernardo Atxaga, representing the local wish and will to defend the Basque language, was condemning.

From a global point of view, linguist David Crystal (2004) believes that nowadays there are three main reasons to believe a language revolution is taking place all around the world: i) English is becoming the global language and, as a result, we can see signs of the emergence and development of different varieties of English in different parts of the world; ii) many languages will disappear over the next few decades; for instance, UNESCO still considers Basque to be an endangered language (UNESCO 2009); iii) the emergence and expansion of the Internet and the changes this implies.

David Crystal thinks that the Internet may be a way to help minority languages to survive and develop: the Internet can be used to preserve and to promote minority languages. It offers enormous possibilities for communication and collaboration and presents an easy way of displaying everyone's "linguistic products" to the entire world in a very short space of time. This is encouraging and motivating for speakers of the language as they can see their language as useful and thus feel proud of it.

The aim of this article is to show some indications of how Basque society is facing the challenge of the Internet and how it is using this new resource in order to preserve not only the presence of Basque but also the quality of the language itself. It is divided into 4 sections: 1) some general information about the situation of Basque; 2) how society is reacting to the Internet; 3 ) some issues about the quality of the Basque language; 4) as an example of work in this area, we present some resources offered by three of civil service institutions intended to help professionals use the Basque language more correctly and appropriately.

\section{Some information about the general situation of the Basque language}

Located on both sides of the western part of the Pyrenees Mountains, the Basque Country has a surface area of 20,947 square kilometers and has about 3,000,000 inhabitants. It has seven provinces; four of them are in the Spanish state and the other three are 
in France. The three provinces in France constitute the Northern Basque Country (Iparraldea in Basque); they belong to the larger French administrative region of Aquitaine, so they do not make up an administrative unit by themselves. The provinces are Labourd (Lapurdi), Lower Navarre (Behe Nafarroa) and Soule (Zuberoa).

The 4 provinces in Spain make up two separate autonomous communities: Navarre (Nafarroa), which is just one province, and the Basque Autonomous Community (BAC), with 3 provinces: Alava (Araba), Guipuscoa (Gipuzkoa) and Biscay (Bizkaia).

So, from the political point of view, three different areas can be distinguished: the Basque Autonomous Community (BAC), Navarre and Iparraldea. The Basque language has a different legal status in each one of them.

Different legal situations. Within the BAC and Navarre, the Basque Language is co-official, along with Spanish. However, while every citizen has a right and at the same time the obligation to know Spanish, all the citizens have a right to use Basque but not the duty to know it. That makes a basic difference in the status of the two languages in society. In the Northern part of the Basque Country, French is the only official language and Basque does not have any legal status.

The language policies carried out in the three areas are different. In the BAC the rights and duties are not the same for the users of the two co-official languages but, within the policy about each language, all the people in the whole territory are given equal treatment; as a result of the language policy carried out by the BAC government, the number of Basque-speakers has increased over the last 20 years. In Navarre, while the Spanish language is equally supported and reinforced throughout the whole territory, with regard to the policy about the Basque language (the lingua navarrorum, as it was called by the Romans 20 centuries ago), the community has been divided into three areas: the Basque-speaking zone, the mixed zone and the non-Basque-speaking zone. In fact, Basque is co-official only in the Basque-speaking zone. However, in spite of this policy of the Government of Navarre, the number of Basque-speakers has slightly increased over the last 20 years. In the Northern Basque Country, there is no active language policy for the Basque language and the number of speakers is continuously decreasing. (For all these data, see Basque Government 2008. The data on the evolution of the number of speakers can be seen on the Net at: http://www.eustat.es). 
Basque in the education system. The education system in the BAC offers the parents three models for Spanish and Basque in nursery and primary schools: model D is teaching in Basque with Spanish as a subject; model B uses both languages for teaching and learning the subjects and areas of the curriculum; in model A, Basque is taught as a subject, Spanish being the language used in the schools. In state schools, all parents throughout the BAC have the same right to choose the educational model they want for their children. There are two models in secondary education: D and $\mathrm{A}$ (see Zalbide and Cenoz 2008).

In Navarre there are four models of nursery and primary schools: the three used in the BAC and another one with no Basque whatsoever. Only parents in the Basque-speaking area have the right to choose Basque speaking state schools (Oroz and Sotés 2008). In the mixed zone, parents have to fight against government restrictions for Basque speaking schools.

In the three provinces in France, finally, Basque is allowed to some extent in the education system, but it is not recognized as an official language by the French authorities.

Some sociolinguistic features. In the following lines we present some sociolinguistic features about Basque, paying special attention to the possibility of forming compact communities of Basque-speakers.

The number of Basque-speakers over 16 years old can be seen in Table 1.

Table 1. Number of Basque speakers in each political area (>16 year old).

\begin{tabular}{|c|c|c|c|c|}
\hline & $\begin{array}{c}\text { Basque } \\
\text { speakers }\end{array}$ & $\begin{array}{c}\text { Passive } \\
\text { Basque } \\
\text { speakers }\end{array}$ & $\begin{array}{l}\text { Not Basque } \\
\text { speakers }\end{array}$ & $\begin{array}{c}\text { Total } \\
\text { speakers }(> \\
16 \text { years old) }\end{array}$ \\
\hline BAC & $\begin{array}{c}558,000 \\
(30 \%)\end{array}$ & $\begin{array}{c}340,000 \\
(18 \%)\end{array}$ & $\begin{array}{c}953,000 \\
(52 \%)\end{array}$ & $\begin{array}{l}1,851,000 \\
(100 \%)\end{array}$ \\
\hline Navarre & $56,000(11 \%)$ & $40,000(8 \%)$ & $\begin{array}{c}414,000 \\
(81 \%)\end{array}$ & $\begin{array}{l}510,000 \\
(100 \%)\end{array}$ \\
\hline $\begin{array}{c}\text { Northern Basque } \\
\text { Country }\end{array}$ & $52,000(23 \%)$ & $20,000(\% 8)$ & $\begin{array}{c}158,000 \\
(69 \%)\end{array}$ & $\begin{array}{l}230,000 \\
(100 \%)\end{array}$ \\
\hline Basque Country & $\begin{array}{c}666,000 \\
(26 \%)\end{array}$ & $\begin{array}{c}400,000 \\
(15 \%)\end{array}$ & $\begin{array}{c}1,525,000(\% \\
59)\end{array}$ & $\begin{array}{c}2,591,000 \\
(100 \%)\end{array}$ \\
\hline
\end{tabular}

Source: Basque Government 2008 
While practically all the population can speak either Spanish or French (depending on their citizenship), people who can not speak Basque are majority in all three political communities (59\% of the whole population). These general percentages are not equally distributed in all the regions and zones. The differences between the provinces can be seen in table 2 .

Table 2. Different percentages of speakers by provinces and political areas (2006).

\begin{tabular}{|c|c|c|c|c|c|}
\hline & \multicolumn{3}{|c|}{ BAC } & \multirow{2}{*}{$\begin{array}{l}\text { Navarre } \\
\text { Navarre }\end{array}$} & \multirow{2}{*}{$\begin{array}{l}\text { Iparraldea } \\
\text { Iparraldea }\end{array}$} \\
\hline & Alava & Biscay & Guipuzcoa & & \\
\hline Bilingual & $14 \%$ & $23 \%$ & $48 \%$ & $11 \%$ & $22 \%$ \\
\hline Passive Bilingual & $20 \%$ & $19 \%$ & $16 \%$ & $8 \%$ & $9 \%$ \\
\hline Monolingual & $66 \%$ & $58 \%$ & $35 \%$ & $81 \%$ & $69 \%$ \\
\hline
\end{tabular}

Source: Basque Government 2008

In most of the regions inside each province, the percentage of Basque speakers is smaller than that of Spanish (or French) speakers (EUSTAT 2001-2006). One significant consequence of this is that in most areas Basque speakers live in an environment that makes it difficult for them to carry on their everyday life in Basque, so that the possibility of creating virtual communities via the Internet could be interesting for people who want or need to improve their proficiency in Basque.

Another significant piece of information for this article is that 38,957 adults were taking different courses to learn or improve their proficiency in Basque (2008/2009 academic year) (EUSTAT 2010). It is also worth mentioning the Basque diaspora around the world, with 171 Basque Centres in 24 countries (Basque Government Presidency 2010 and Uberuaga: http://buber.net/Basque/). It is also estimated that about one thousand students are taking Basque courses in nearly 30 universities outside the Basque Country.

The Internet can help people to build virtual communities, having access to some facilities that the geographical distribution of Basque-speakers makes it more difficult to obtain.

The normalization of Basque. The normalization process of Basque began academically in the 1960s and started receiving institutional support around 1980. Basque had never been com- 
monly used in official areas such as administration and the education system until the beginning of this process of normalization. At that time, Basque was mainly used in rural areas with low levels of industrialization. As a result, it was scarcely developed in some areas related to industrial society. So one of the most important concerns of normalization was to prepare and develop the language to deal with every aspect of urban and industrial society and it began to be used in all the contexts of a mostly urban and industrial society (Euskaltzaindia 1977).

The standard variety and the dialects of Basque. According to Zuazo (2008), there are 5 dialects of Basque (Euskara). The standard variety of the language (Euskara batua) is mainly based on the central dialects and it is the most widely used variety in education, from nursery schools to university. The progressive linguistic development and fixing of the standard variety occurred partially at the same time as it was incorporated into the state education system, and a large number of teachers received the training and qualifications needed to teach in Basque as adults (Sierra 1993).

\section{Basque (and society) and the Internet}

David Crystal (2004) points out that motivation is needed in order to create a virtual space strong enough to preserve and defend minority languages; he also points out that achieving these objectives for any minority language requires a critical mass.

According to Uberuaga (2001), Basque began to be used on the Internet around 1993 or 1994 . At the beginning of the 21th century he was concerned about the effect of the world-wide spread of the Internet on languages and cultures other than English. Below, we point out some indicators to show how Basque society is reacting to the challenge of the Internet with regard to the Basque language. We will look at the work carried out by government, universities and some other organizations.

But, first of all, it is worth mentioning some data on the use of the Internet in the land of Euskara. In 2009, the percentage of dwellings having Internet access in the BAC and Navarre was higher than the Spanish average (54\%) and the percentage of frequent Internet users was $57.6 \%$ in Navarre and $56 \%$ in the BAC (INE 2009). In France, the percentage was $65 \%$ (EUROSTAT 2009). 
The Royal Academy of the Basque Language, Euskaltzaindia, is doing important work to offer more and better services to people interested, especially using the Internet. Later on in this article we will show some of its services for taking care of the quality of the Basque language in more detail (http:// www.euskaltzaindia.net ).

The BAC government's work. There is information on the Web about the two plans drawn up by the BAC government in 2001 and 2007 (Basque Government 2001 and 2007). Basque is specifically taken into account in both of them. More recently, the Basque Autonomous Community government has been trying to reach a new agreement for the whole society about the basis of the general language policy to be held for the next 25 years. Ideas are offered to create and reinforce both real and virtual communities and there is a specific reference to the use of the new Information and Communication Technology (ICT) to develop Basque. In order to normalize the language and to give speakers a better chance to use it, it encourages the creation of contents in Basque to put on the Web. The use of ICT is thought to be necessary in order to develop the language completely (Euskararen Aholku Batzordea 2009).

Society's reaction seems to be quite active: in BAC government's catalogue there are more than 330 projects connecting ICT and the Basque language (Basque Government 2009).

The universities. There are seven universities in the 7 provinces of the Basque Country. We will look at some information about their concerns and commitments in relation to the Basque language.

Since its very beginning in 1980, the BAC public university, the UNIVERSITY OF THE BASQUE COUNTRY (UNIVERSIDAD DEL PAÍS VASCO-EUSKAL HERRIKO UNIBERTSITATEA: http://www.ehu.es/p200-home/eu) has paid special attention to the use and development of the Basque language; it has a Vice-Chancellor in charge of Basque and issues concerning multilingualism (http://www.euskara-errektoreordetza.ehu.es/p267home/eu/); about 1,500 teacher-jobs are bilingual Spanish-Basque. MONDRAGON UNIBERTSITATEA was created in 1997 and it also has a great commitment to the development of the Basque language; its website has three versions, in Basque, Spanish and English (http://www.mondragon.edu/home/); many university subjects are taught in Basque. THE UNIVERSITY OF DEUSTO also has a 
trilingual web page, Spanish-Basque-English; in most of the undergraduate degrees some subjects are taught in Basque (see reference: University of Deusto). The web site of the PUBLIC UNIVERSITY OF NAVARRE (UPNA-NUP) offers information in Spanish, Basque and English (http://www.unavarra.es/); some subjects of its undergraduate courses are also taught in Basque. The UNED has a bilingual homepage; it offers a Postgraduate Writers' School in Basque (http://www.uned.es/ca-bergara/ ). The private UNIVERSITY OF NAVARRE, which belongs to a religious organization, has two versions of its website, using Spanish and English, but nothing in Basque (http://www.unav.es/). Finally, in the Northern Basque Country, the UNIVERSITÉ DE PAU ET DES PAYS DE L'ADOUR has a trilingual web page (French, English, Spanish) on which Basque is not used (http://www.univ-pau.fr/live/); a very few subjects are offered in Basque.

It should also be taken into account that there are two faculties of computer science in the Basque Country (one at the UPVEHU, the other at the University of Deusto). A highly active research group dedicated to fostering the Basque language at the University of the Basque Country is also noteworthy (see reference: IXA).

Other organizations and voluntary movements. There are a number of established organizations working in the Basque language area covering different aspects of normalization and modernization. Among others, we mention the following: UEU has the objective of building bridges between Basque and universities, bringing together members of the Basque-speaking scientific and intellectual community (http://www.ueu.org/); ELHUYAR's work is to promote interest in science and technology and to create and offer language-related facilities for developing and normalising Basque (http://www.elhuyar.org/); UZEI (Basque Centre for Terminology and Lexicography) is a non-profit professional organization which aims to modernize the corpus of Basque for speakers to be able to use their language accurately and precisely in any specialist area (http://www.uzei.com/home.asp); EUSKO IKASKUNTZA is the only multidisciplinary scientific organization officially established in the BAC, Navarre and the Northern Basque Country and its objective is to be a constant actor in the development of Basque culture (http://www.eusko-ikaskuntza.org/en/).

In terms of voluntary movements involved in the promotion of Basque in the virtual world, there is a current attempt to get an 
Internet domain accepted with the letters .eus (initials of the Basque language -euskara- and Basque Country -Euskal Herria-). More than 25,000 signatures were collected for this at the beginning of 2009 in just 3 weeks (http://www.puntueus.org/eu/ ).

With these few examples we intend to show that the Basque community is aware of the importance of using the Internet and how it is reacting to take advantage of this new technological resource.

\section{The quality of the Basque language and the Internet}

We understand that good quality language means using the language correctly and appropriately. In other words, good quality language is when communication between every kind of speaker has been done efficiently. This concept of language quality is closely related to the context of the act of communication, and it goes beyond grammatical correction (Euskararen Aholku Batzordea 2004). However, in this article we are focusing on formal communication contexts, where educated users deliberately seek the best development of the language in its formal usage.

We argue that the Internet is helpful for preserving and fostering the language quality of Basque because it provides useful tools to satisfy different needs in the development of this minority language. In this respect, the tools offered by the Web can be used in two senses. Firstly, the Web offers an excellent opportunity to spread knowledge about the tradition and good uses of the language among people interested. Secondly, it gives language professionals a powerful way of collaborating in the shared task of looking for the best solutions for new communication needs when information given by tradition is not clear or well known enough.

Over the next paragraphs we will reflect briefly on these two aspects of consulting tradition and looking for collaboration over the Web. We will then try to explain which groups of people may be interested in the possibilities offered by the Internet given the particular circumstances of the Basque language.

Consulting tradition and looking for collaboration. At the time of the death of the dictator Franco (1975) and over the following years, there was an evident lack of wide-spread knowledge about the tradition and correct use of the language. Very few 
people were able to state which the correct usages of the language were because Basque had neither been widely studied academically nor that knowledge had a chance to be spread through the education system. However, the demand for education in Basque rapidly increased (particularly in the BAC but also in Navarre) and many teachers began to use Basque in school activities in spite of the lack of well known and established tradition. Over the last thirty years, language tradition has been studied quite intensively, mainly at the universities and the Royal Academy of the Basque language. As a result, knowledge about the tradition and correct usages of the language is steadily increasing, so that language professionals who want to be up-to-date must somehow get the information they need for their work. The Web provides people interested with very powerful tools to get in virtual touch with linguistic authorities in order to obtain that information in a rapid, easy and non expensive way. In these cases the knowledge is already established and collected by specialists, so that all that people interested have to do is look for the information they need in the correct place (later on we will present some of those current resources).

In other cases, however, looking at these places where tradition is analyzed may be not enough to find the best solution. This happens in the fields of activity where Basque has not been used enough in order to construct and consolidate a well established, widely known and unchallenged tradition. For instance, university teaching and research using Basque in almost every area of scientific activity (although that situation has changed over recent decades) and the different areas where translators, going before the common users of the language, offer solutions to the communication challenges they have to cope with. When it is necessary to look for new forms of expression for unusual communicative demands (as in the two above-mentioned cases), collaboration among experts and professionals in each area can be crucial in order to study the tradition (which sometimes is not obvious or well enough known) in more detail as well as to find new solutions for problems never faced before. In both cases, the Internet can be of great help to establish contact and collaboration in a very efficient way, supplying different ways for building virtual communities among people interested from all around the world. Nowadays, for instance, in the area of translation there is an active distribution list called itzulist (http://www.eizie.org/Tresnak/Itzul) which is useful for translators to get in touch with each other in order to solve the 
problems they have to cope with in collaboration (the association of translators EIZIE has nearly 300 members).

Potential users of Internet resources for the quality of the Basque language. Language professionals such as writers, politicians, teachers at all levels of the educational system, translators, journalists, lawyers and public administration workers are decisive for development. They act as models for other people and common users of the language and their performances are collected in corpora that are used to study the current usage of the language. Due to the dynamic process of normalization and standardization, the members of these collectives need to have updated information on the decisions made by the linguistic authorities on the correct patterns of language usage. Some time ago it was quite usual to find people angry with the language authorities because of the great amount of changes the Academy of the Basque language was believed to make on its own previous decisions. Most of the complaints were probably due to a lack of good channels to communicate these decisions. Nowadays the Internet provides people interested with a very efficient way to share this sort of information.

Looking at some current outcomes of bilingual education in the Basque Country can also be useful to give us information about the linguistic proficiency of the young generations and their possibility of being users of linguistic resources in order to improve it. There are a considerable number of not completely bilingual people who may also be interested in getting information to improve their linguistic skills. In a study carried out in the BAC by the Basque Institute of Institutional Assessment on students at the end of the compulsory education (at 16), Basque language proficiency has been reported as being insufficient in a significant amount of cases: the suitable B2 level of the Common European Framework of Reference for Languages was not reached in Basque by about one third of the pupils who attended model D schools (all the subjects in Basque except for Spanish as a subject) and by more than two thirds of the pupils having studied in model B schools (half of the subjects in Basque and half in Spanish) (ISEI-IVEI 2005, Sierra 2008).

Another study carried out on the first-year students in two faculties of the University of the Basque Country (UPV-EHU) points out that some common features of the Basque language based on the most widely accepted tradition are being challenged by the arrival of other features that make communication difficult. About a 
hundred grammatical and lexical features were studied: the average student accepted more than $50 \%$ of the new forms, challenging traditional uses of Basque (Maia, Beldarrain and Serna 2007).

So it can be forecasted that some of the students who have had bilingual education will need to further develop their linguistic competence if they want to succeed in activities where a good command of Basque is required, such as teachers at all the levels of the educational system, journalists, translators, public administration workers, lawyers, etc.

Members of the Basque diaspora could also be interested in getting information about the correct and appropriate usage of the language, as well as other people around the world involved in Basque matters, such as the students taking courses on Basque language and culture at nearly 30 universities outside the Basque Country.

Finally we point out that, in general, in many places of the Basque Country Basque speakers often live in a linguistic environment where Spanish (or French) is dominant, so that the possible lack of real Basque-speaker communities can be balanced to some extent by the creation of virtual communities.

So there are a considerable number of potential users of the services intended to protect or improve the quality of Basque. In this sense the Internet is already being very useful: on the one hand, it can provide people interested with materials to improve the process of language learning within all the educational levels, even in the Basque Country itself; on the other hand, the Internet provides people across the world with a very powerful tool for lifelong learning (which is considered one of the most important issues to be faced by modern knowledge society), without spending a great deal of time or money. The Internet offers powerful tools to draw the users of a language together and to reach a better level of linguistic cohesion through the creation of virtual communities.

\section{Some resources offered on the Internet by offi- cial institutions taking care of the language quality}

It has been pointed out that there are a number of private institutions making a great contribution to the normalization of Basque. In the following lines, however, we will only refer to some 
resources offered by three official institutions in order to preserve and foster the quality of Basque: a) The Basque Civil Service Institute (IVAP-EHAA); b) The Royal Academy of the Basque Language (Euskaltzaindia); c) The University of the Basque Country (Universidad del País Vasco-Euskal Herriko Unibertsitatea, hereinafter referred to as UPV-EHU).

The Administrative Section of the Basque Government offers an interactive asynchronous service called DUDA-MUDA (see reference: DUDA-MUDA), intended to give advice and solve doubts on legal and administrative texts, an area where Basque has little tradition. The requests for advice are responded to via e-mail by the research team in charge of the service. The proposed solutions are not compulsory rules but only pieces of advice. All the answers to previous questions are kept in a database put at users' disposal. Similar interactive asynchronous facilities are offered by the Academy of the Basque language and the University of the Basque Country (see below).

The Royal Academy of the Basque Language, Euskaltzaindia, plays a crucial role in the Basque normalization and standardization process. Among other work areas, it mainly takes decisions about the rules for the standard variety of the language, euskara batua, including its dictionary (http://www.euskaltzaindia.net/arauak). Thanks to the Internet, these decisions can be known in a very short time by all teachers and students, journalists, translators and other public administration workers, as well as by other people interested in general. Using the Internet, communication and linguistic cohesion between the Academy and the community of speakers has improved dramatically. In addition, the 16 volumes of the General Basque Dictionary (Orotariko Euskal Hiztegia) are also available in electronic format (http://www.euskaltzaindia.net/iker_jagon/ bilatzaileak), as is the statistic corpus of 20th century Basque (http:// www.euskaracorpusa.net/XXmendea/index.html). Among other resources supplied by the Academy via Internet, JAGONET is an advisory service intended to offer the professionals aid in the correct, appropriate use of Basque (http://www.euskaltzaindia.net/ jagonet/); as well as a database built up with the answers given to the previous inquiries, this service allows people interested to ask the Academy specific questions about their doubts, looking for the best solutions according to academic standards.

The University of the Basque Country (UPV-EHU) (http:// www.ehu.es/p200-home/es/) makes an important contribution to 
the normalization of Basque. Coming from a completely Spanish speaking university, during the last 30 years it has made a significant effort to respond to the demand for teaching in Basque. Led by the Vice-Chancellor for Basque and Multilingualism (http:// www.euskara-errektoreordetza.ehu.es/p267-home/es/), the UPVEHU has a policy with different branches, aiming to help university teachers and administrative staff to face the problems arising in their everyday work, as well as giving a service for students and the Basque-speaking community in general. We point out some resources where the Internet plays an important role. There are one-way consulting materials as well as interactive ones; in addition, some tools offered by the Web are useful for publishing materials as well as for improving collaboration between professionals involved in issues related to the quality of the Basque language.

There are some corpora available to consult contemporary usage of the language. Among them, EREDUZKO PROSA GAUR (Contemporary Reference Prose) is a corpus of more than 25 million text-words, chosen from selected Basque prose writings (20012007). It offers patterns to choose a solution looking up words as they are used today by Basque writers (http://www.ehu.es/euskaraorria/euskara/ereduzkoa/).

EHULKU is another service offered by the UPV-EHU to promote the correct and appropriate usage of Basque through the Internet (http://www.ehu.es/ehulku/). It aims at offering solutions for the language problems faced in university teaching and research using Basque, in every subject (in both common and scientific language), in an interactive way: teachers of the UPV-EHU can ask for advice on any particular doubt. All the previous questions and answers are collected in a database and put at the disposal of potential users. Another service is also available: after being registered on a distribution list, more than 1,800 users regularly receive pieces of advice about a chosen linguistic issue considered relevant by the people who run the service and later these pieces can be permanently consulted on a website called "EHULKU service's recommendations", in power point format.

EHUTSI is another open service offered by the UPV-EHU which is available on the Internet for all users of the language (http://www.euskara-errektoreordetza.ehu.es/p267-shehuthm/eu/). It presents exercises to first identify and then help to correct about a hundred typical mistakes made in Basque usage. It uses translations from Spanish as a resource to reflect on tradition and to 
improve awareness of it. It also provides additional information to look for deeper knowledge of the item under consideration; when available, users can go straight to complementary sources by means of a link in the text.

AZPIDAZKI (http://www.ehu.es/azpidazki/default.asp) is intended to help administrative staff do their work in Basque. Many of the administrative workers of the UPV-EHU have a limited command of Basque and AZPIDAZKI offers some templates for their everyday work.

It is significant that among the facilities we have reviewed there are many links to other institutions involved and available sources (for instance, the Language Academy Euskaltzaindia and several dictionaries on the Net).

Finally, the Internet offers a very powerful tool for reviewing texts before publication. Through the Web, the relationship between creators and reviewers is rapid (though not necessarily always very friendly!), no matter where they are physically in the world. This is a great advantage when the organization in question establishes a standard of language quality for material before it is published. UPV-EHU has such a "checking up service" which is applied to the creation of teaching materials by teachers as well as to the translation of other basic or complementary materials. The resources supplied by the Internet are a great help in two ways and at two times during that process: first, communication and collaboration among professionals during the creation of the materials help to improve the end product; then, when the time for publishing arrives, the Internet offers the possibility of electronic publishing on the Web, which has some advantages: firstly, the cost and difficulty of publishing decreases significantly; secondly, changes can be dynamically carried out on materials not definitely fixed (because the on-going normalization process itself). In about 5 years nearly 90 items of such materials in book-format have been published on the Net (http://testubiltegia.ehu.es/).

\section{Conclusion}

The normalization process of Basque is still ongoing. In cases like this, collaboration, information sharing and some kind of consensus among professionals is more necessary than in cases when the language has reached greater levels of normalization and stan- 
dardisation. In other words, a good level of cohesion among the users helps in the normalization of the language. One particular kind of cohesion is that specifically affecting the linguistic part of normalization; it is important for professionals and users to know the features and the boundaries of "good-quality language" as well as possible.

We can point out some elements that help to know (and even to define, in some cases) these features and boundaries:

a) the knowledge of the linguistic rules offered by the Academy of the Basque Language, Euskaltzaindia, and all the decisions made on the linguistic features of the unified language are crucial elements for many professionals who need them in their everyday life: teachers at all educational levels, journalists, translators, etc. are looking forward to knowing these decisions, usually based on the most widely accepted tradition;

b) other professional groups also need to make decisions about the use of their specific language every day. For instance, university teachers and researchers in every scientific area, as well as translators. In such cases, sometimes there is no specific Academy rule nor any well established and widely known tradition that can be used and professionals of each specific area will probably find a better linguistic solution if they share information, debate the subject, make different proposals and correct each other before reaching a consensus on the matter.

The Internet provides resources to obtain these advantages. Specifically, it offers the possibility of web sites where people interested can either look for good patterns in the use of Basque, or find materials to identify and correct common mistakes in the speakers' linguistic behaviour. Questions can also be asked to get advice on different linguistic subjects, offered by different providers, in different fields of activity. We have shown above a sample of these materials and resources which can be, in addition, enlarged and improved dynamically.

In addition, the Internet offers very easy ways to debate different options for choosing the best solution, for making proposals and corrections, and reaching agreements among experts and professionals (distribution lists for people interested, electronic mail, specific blogs...). Furthermore, publishing in electronic format is cheaper and easier than other ways and documents available on the Web can 
be accessed worldwide. This is also very important when the language to be promoted does not have a large number of speakers and the speakers are not all concentrated in compact groups.

Therefore, taking into account all those considerations, we conclude that the Internet in fact supplies useful tools and resources to preserve and foster the Basque language and, specifically, its linguistic quality. However, it is necessary to know where those resources are and, of course, to use them. In the end, the possibilities offered by the Internet must be matched with the sensitivity of the whole society to use Basque with a degree of quality that preserves and guarantees its communicative capability in the changing world we live in as far as possible.

\section{Addresses:}

Julian Maia-Larretxea

Lonbo kalea, $13,4^{\circ} \mathrm{C}$

Arrigorriaga 48480 (Bizkaia)

Spain

E-mail:julian.maia@ehu.es

Kepa Larrea-Muxika

Kurutzea kalea, $11,1^{\circ} \mathrm{F}$

Arrigorriaga 48480 (Bizkaia)

Spain

E-mail: kepa.larrea@ehu.es

\section{References}

Basque Government (2001) Plan Euskadi en la sociedad de la información. http://www.euskadi.net/eeuskadi/new/es/adjuntos/Plan.pdf

Basque Government (2007) Segundo Plan Euskadi en la sociedad de la información. 2.0 La agenda digital de Euskadi 2010. http://www.euskadi.net/ r33-2287/es/contenidos/enlace/pesi2010/es_pesi2010/adjuntos/PESI2010 c.pdf

Basque Government (2008) IV Encuesta sociolingüística de Euskal Herria. http://www.kultura.ejgv.euskadi.net/r46-17894/es/contenidos/informacion/ argitalpenak/es_6092/adjuntos/IV_incuesta_es.pdf

Basque Government (2009) http://www.euskara.euskadi.net/r59-19678x/eu/ t06aInventarioWar/t06aInicioServlet?idioma=e

Basque Government. Presidence (2010) http://www.lehendakaritza.ejgv.euskadi.net/ r48-3872/en/contenidos/informacion/03_listado_centros/en_lista/centros.html 
Cenoz, J. (2008) “Achievements and challenges in bilingual and multilingual education in the Basque Country". AILA review 21, 13-30.

Crystal, D. (2004) The language revolution. Cambridge: Polity Press Ltd.

DUDA-MUDA. http://www.ivap.euskadi.net/r61-v50001x/eu/v50aWar/ comunJSP/v50acambioIdioma.do?v50aCgaIdioma=eu

ELHUYAR. http://www.elhuyar.org/hizkuntza-zerbitzuak/EN/A-ComprehensiveLanguage-Service

EUROSTAT (2009) Individuals regularly using the Internet. http://epp. eurostat.ec.europa.eu/tgm/table.do?tab=tableandplugin= 0andlanguage =enandpcode $=$ tin00061

Euskaltzaindia (1977) El libro blanco del euskara. Bilbao: Euskaltzaindia

Euskaltzaindia. http://www.euskaltzaindia.net/

Euskararen Aholku Batzordea (2004) Euskararen kalitatea. Zertaz ari garen, zergatik eta zertarako. Vitoria-Gasteiz: EJAZN-Servicio Central Publicaciones Gob. Vasco.

Euskararen Aholku Batzordea (2009) Itun berritu baterantz. Gogoeta irekiaren ondorengo txostena. Vitoria-Gasteiz: EJAZN- Serv. Centr. Publ. Gob. Vasco.http://www.euskara.euskadi.net/r59-738/eu/contenidos/informacion/ eusk_aholku_batzordea_nabarmen/eu_2009/adjuntos/euskara21.pdf

EUSTAT (2010) Adults learning Basque. http://www.eustat.es/elementos/ ele0000400/ti_Euskaltegiak_eta_heldu_euskaldunduak_eta_alfabetatuak _euskaltegi-motaren_eta_lurralde_historikoaren_arabera _2008-2009/ tbl0000498_e.html

EUSTAT (2001-2006) Population and housing census. http://www.eustat.es/ci_ci/ estadisticas/idioma_i/tema_98/opt_0/tipo_1/ti_Population_and_housing census/temas.html

INE (2009) http://www.ine.es/en/prensa/np570_en.pdf

ISEI-IVEI (2005) Level B2 in Basque at the end of obligatory education. http:/ /www.isei-ivei.net/eng/pubeng/B2_ENGLISH1.pdf

ITZULIST. http://www.eustat.esWWW at http://www.eizie.org/Tresnak/Itzul

IXA. http://ixa.si.ehu.es/Ixa

Maia, J., A. Beldarrain, and M. Serna (2007) "Estudio para la mejora de algunos aspectos de la producción escrita en euskera de estudiantes de Magisterio y de Periodismo de la UPV-EHU”. In J. Ramírez, ed. La lengua escrita, 575-582. Barcelona: SEDLL.

Oroz Bretón, N. and P. Sotés Ruiz (2008) "Bilingual education in Navarra: achievements and Challenges". Language Culture and Curriculum 21, 1, 2138 .

Ruiz Olabuenaga et al. (1983) La lucha del euskera en la Comunidad Autónoma Vasca: una encuesta básica: conocimiento, uso, actitudes. VitoriaGasteiz: Servicio Central de Publicaciones del Gob. Vasco. 
Sierra, J. (1993) “Las lenguas en el sistema educativo del País Vasco. In M. Siguàn. Enseñanza en dos lenguas. Barcelona: Universitat de Barcelona-Horsori. Sierra, J. (2008) “Assessment of bilingual education in the Basque Country”. Language Culture and Curriculum 21, 1, 39-47.

UNESCO. (2009) http://www.unesco.org/culture/ich/UNESCO-Endangered Languages-WorldMap-20090218.pdf

University of Deusto. http://www.deusto.es/servlet/Satellite/Page/1101307572844/ _ingl/\%231101307572844/c0/Inicio.

Uberuaga, B. P. (2001) The Basque presence on the internet: yesterday, today and tomorrow. http://www.buber.net/Basque/Web/basque_rev4.pdf

Zalbide, M. and Cenoz, J. (2008) "Bilingual education in the Basque Autonomous Community: achievements and challenges" Language Culture and Curriculum, 21, 1, 5-20.

Zuazo, K. (2008) Euskalkiak, euskararen dialektoak. Donostia-San Sebastián: Elkar.

Kokkuvõte. Julian Maia-Larretxea, Kepa Larrea-Muxika: Internet baski keele kvaliteedi säilitaja ja soodustajana. Käesoleva artikli eesmärk on näidata, kuidas baski ühiskond puutub kokku Interneti väljakutsetega ja kuidas seda uut ressurssi kasutatakse mitte ainult baski keele olemasolu, vaid ka keele kvaliteedi säilitamiseks. Artikkel on jagatud nelja ossa: 1) üldine informatsioon baski keele kohta, 2) kuidas baski ühiskond suhtub Internetti, 3) mõned probleemid seoses baski keele kvaliteediga (teenused, mida saab osutada läbi Interneti, ja nende potentsiaalsed kasutajad), 4) mõned ressursid, mida pakuvad kolm eraettevõtet eesmärgiga aidata ametnikel kasutada baski keelt korrektsemalt. Lõpuks järeldame, et Internet pakub tõepoolest kasulikke vahendeid ja ressursse baski keele ja eriti selle kvaliteedi säilitamiseks ja soodustamiseks. Teiselt poolt on ühiskond üsna teadlik selle uue abivahendi tähtsusest ja suhtub hästi nimetatud uue tehnoloogia väljakutsetesse.

Märksõnad: vähemuskeel, Internet, baski keel, keele kvaliteet 
